\title{
Views on Piracy: Threats to International Peace
}

\author{
Alimen A. Rolando, Jeson C. Fernandez and Cesar I. Mongan \\ John B. Lacson Foundation Maritime University, Philippines
}

\begin{abstract}
The study was conducted to ascertain the views on piracy among marine engineering students and marine officers who had encountered piracy on international waters thereby suggesting threats to international peace. The respondents of the study were 50 , specifically distributed to thirty (30) onboard marine engineering students enrolled for the current school year 2014-2015 and twenty (20) marine officers who had experienced piracy at Somalia and other places. The researchers employed quantitative-qualitative research method design. The questionnaire on "Piracy at Sea" was validated by experts in research, statistics, qualitative research, and maritime international conventions. To test the reliability, this same instrument was pilot-tested among marine officers and students who had been on board international ships. Qualitative data were captured through interviews by using open-ended questions. Frequency count, percentage, and rank were used in this study for descriptive-quantitative statistics. The data were analyzed using appropriate statistics through computer-processed software (SPSS). Qualitative analysis was employed to determine the views of the respondents on piracy so that mitigation measures were elicited for protection of life at sea leading towards international peace among identified HRAs (high-risk areas). Results revealed that seafarers were familiar of piracy. They were aware that piracy usually happens in areas like Somalia water sand other threatening territories. To combat piracy, the participants have pointed out the role of the international community in their concerted effort to help seafarers safeguard their lives specifically during these hard times. Somalia also needs to effectively check their organization by whether or not strict implementation of the Anti Piracy Law was being observed. Full knowledge of piracy, techniques for avoiding it, and surviving pirate attacks are necessary among seafarers. Satellite system called shiplock allows shipping companies to monitor location of ships particularly useful during pirate attacks, hijacks, or ship theft. They also install non-lethal electrical fences around a ship’s perimeter to protect them during these times. IMO regulations require ships to send distress signals and warnings covertly in case of pirate attacks.
\end{abstract}

Key words: Piracy, threats, international peace, maritime university, marine engineering students, marine officers, high-risk areas (HRAs), satellite system, international community.

\section{Introduction}

Piracy is an illegal act of violence or detention, or any act of depredation, committed for private ends by the crew or the passengers of a private ship or a private aircraft. Last year, reports show that pirates took 1,181 people hostage off the Srepomali coast. About half were released after the payment of ransoms, a few have died of abuse or neglect and around 760 are currently in captivity. They are usually held prisoner on their own hijacked vessels, some of which are employed as mother-ships from which the pirates stage further raids (The Economist, 2011).

According to this report, there have been 35 attacks, seven of them successful. The problem has worsened

Corresponding author: Alimen A. Rolando, Ph.D., research fields: maritime education, engine-room simulator, marine environment. sharply in recent years. There were 219 attacks last year compared with 35 in 2005. Ransoms paid climbed to \$238 Million, an average of \$5.4 Million per ship, compared with $\$ 150,000$ in 2005. At the end of last month Jack Lang, a former French minister who advises the UN on piracy, warned the Security Council that Somali pirates were becoming the "masters" of the Indian Ocean. He puts the economic cost of piracy at \$5 Billion to \$7 Billion a year. The price in human misery is unquantifiable. Acts of piracy and armed robbery against ships are of tremendous concern to IMO and to shipping in general. The fight to prevent and suppress these acts is linked to the measures to improve security on ships and in port facilities, adopted in December 2002. Modern day pirates still rely on speed and surprise in their attacks. They use fast dinghies and arm themselves with assault rifles to 
overpower ships. Many ships today have smaller crews, relying on technology and so can be easily overpowered.

JBLFMU-Molo, having been a major source of seafarers, is also aware of this phenomenon. In fact, the researchers know for a fact that a number of the graduates who had been plying international waters for sometime opted to retire early because of their traumatic experiences on piracy.

As a maritime university, it is also advocating on a massive information drive about emergency measures in times of piracy. Thus, this study was one of those little advocacies conducted by the university to equip maritime cadets of the knowledge about piracy in relation to their work in the future.

\section{Statement of the Problem}

The present study ascertained the views on piracy among marine engineering students and marine officers who have encountered piracy on international waters thereby suggesting mitigating measures to protect life at sea. Specifically, this study sought answers to the following questions:

(1) Are the marine engineering students and marine officers aware of the piracy at sea?

(2) Is piracy a threat to international peace?

(3) What are their common views and understanding of piracy at international sea?

(4) What are their views for considering piracy at sea as threat to international peace?

(5) What ways were suggested to combat piracy to attain international peace?

\section{Method}

The respondents of the study were 50 participants, specifically distributed to thirty $(30,60 \%)$ marine engineering students, who had been on-board and enrolled for school year 2014-2015 and twenty (20, $40 \%$ ) marine officers who have experienced piracy at Somalia and other places. The researcher employed quantitative-qualitative research method design. The questionnaire on "Piracy at Sea" was validated by experts in research, statistics, qualitative research, and maritime international piracy. Reliability was established for the purpose of this study. Qualitative data and views were captured by using interview based on open-ended items on the questionnaire. Permission to conduct the study was secured from the Dean of the college where the marine engineering students and marine engineers belonged. The frequency count, percentage, and rank were used for the descriptive-quantitative analysis. The data were analyzed using appropriate statistics through computer-processed software (SPSS). Qualitative analysis was employed to determine the views of the respondents on mitigating measures to protect seafarers' life at sea in the achievement of international peace among HRAs (high risk areas).

Table 1 shows the distribution of the respondents. There were 50 (100 percent) comprising 30 (60 percent) marine engineering students and 20 (40 percent) marine engineers/officers.

\section{Results and Discussion}

Results were based on the questions advanced in this study. When the respondents were asked if they were aware of piracy at sea, all of them 50 (100 percent) were aware.

Table 1 Distribution of the participants.

\begin{tabular}{lll}
\hline Category & $f$ & $\%$ \\
\hline Entire group & 50 & 100 \\
Marine engineering students & 30 & 60 \\
Marine engineers/officers & 20 & 40 \\
\hline
\end{tabular}

Table 2 Awareness on piracy at sea.

\begin{tabular}{lll}
\hline $\begin{array}{l}\text { Are the participants aware of the } \\
\text { piracy at sea? }\end{array}$ & $f$ & $\%$ \\
\hline Yes & 50 & 100 \\
No & 0 & 0 \\
\hline
\end{tabular}

Table 3 Piracy as threat to international peace.

\begin{tabular}{lll}
\hline $\begin{array}{l}\text { Is piracy a threat to international } \\
\text { peace? }\end{array}$ & $f$ & $\%$ \\
\hline Yes & 48 & 96 \\
No & 2 & 4 \\
\hline
\end{tabular}




\subsection{Piracy as Threat to International Peace}

When participants were asked if they were aware of piracy at sea, majority of them 48 (96 percent) said that they were aware of piracy at sea. Only two (4 percent) said that they were not aware.

\subsection{Views on Piracy at Sea}

When they were asked of their views/opinions/understanding of piracy at sea, piracy at sea is the biggest problem to international shipping nowadays. The high-risk area is the waterway stretching from Yemen up to the coastline of Somalia from the Gulf of Aden. Ship owners employ private security escorts to prevent its occurrence. In some cases, the US Navy as well as some European Naval ships provides naval escort to protect commercial ships passing the HRA (high risk area). Due to almost non-existence of government in Somalia, Somali people engaged in piracy as a means of livelihood ranked 1 with 11 responses. Piracy at sea is one of the utmost concerns of the world shipping industry, because it endangers the life and property of seafarers at sea and safety of the vessel when vessel uses sea-lane as an alternative to reach its final destination.
Ship owners and concerned parties like the IMO should take precautionary measures for the welfare of the seafarers and the security of ship navigation and commerce ranked 2 with 10 responses. Piracy at sea is a perennial problem of the present seafarers, especially in Gulf of Aden in Somalia. It is the poverty that drives people to participate in this criminal activity-piracy at sea. Piracy at sea is one of the ways that pirates think could alleviate the people from poverty and starvation. However, only those brave and strong persons are luckily hired in performing the operation-piracy at sea. In this situation, piracy at sea shall continue as long as there are vessels navigating in the said HRA ranked 3 with 8 responses. The rest of their views are found in Table 4.

\subsection{Views of Piracy as Threat to International Peace}

When the participants were asked about their views for considering piracy at sea as a threat to international peace, majority of them (14 responses, ranked 1) were: Definitely piracy at sea is considered a threat to international peace for some reasons that shipping industry involved international trade. Shipping companies are owned and operated by international

Table 4 Views/opinions/ understanding of "piracy at sea”.

\begin{tabular}{|c|c|c|}
\hline Views/opinions/understanding about "piracy at sea” & $f$ & Rank \\
\hline $\begin{array}{l}\text { Piracy at sea is the biggest problem to international shipping nowadays. The high risk area is the waterway stretching } \\
\text { from Yemen up to the coastline of Somalia from the Gulf of Aden. Ship owners employ private security escorts to } \\
\text { prevent its occurrence. In some cases, the US Navy as well as some European Naval ships provides naval escort to } \\
\text { protect commercial ships passing the HRA (high risk area). Due to almost non existence of government in Somalia, } \\
\text { Somali people engaged in piracy as a means of livelihood. }\end{array}$ & 11 & 1 \\
\hline $\begin{array}{l}\text { Piracy at sea is one of the utmost concerns of the world shipping industry, because it endangers the life and property } \\
\text { of seafarers at sea and safety of the vessel when vessels use sea-lane as an alternative to reach its final destination. } \\
\text { Ship owners and concerned parties like the IMO should take precautionary measures for the welfare of the seafarers } \\
\text { and the security of ship navigation and commerce. }\end{array}$ & 10 & 2 \\
\hline $\begin{array}{l}\text { Piracy at sea is a perennial problem of the present among seafarers, especially in Gulf of Aden in Somalia. It is the } \\
\text { poverty that drives people to participate in this criminal activity-piracy at sea. Piracy at sea is one of the ways that } \\
\text { pirates think could alleviate the people from poverty and starvation. However, only brave and strong persons are } \\
\text { luckily hired in performing the operation-piracy at sea. In this situation, piracy at sea shall continue as long as there } \\
\text { are vessels navigating in the said HRA. }\end{array}$ & 8 & 3 \\
\hline $\begin{array}{l}\text { Piracy at sea is one of the emergencies which occur aboard ship. Piracy is a kind of business that involved money and } \\
\text { threat to the shipping-industry and business. }\end{array}$ & 7 & 4 \\
\hline The act of stealing the ship's cargoes and properties. & 5 & 5 \\
\hline Piracy is an act of robbery at sea. & 4 & 6 \\
\hline Piracy at sea can be dangerous to seafarers. & 3 & 7 \\
\hline Piracy in seafaring can pose a threat to the life of seafarers. & 2 & 8 \\
\hline
\end{tabular}


owners and therefore if one of their vessels were attacked by pirates the particular country wherein the vessel being registered will react and even retaliate. In this case, there will be a fight between countries involved and therefore there will be a conflict with regards to relationship globally.

In rank 2 was the view: International peace is greatly threatened by piracy. Some terrorist organizations are using piracy to advance their terroristic agenda by employing piracy to raise funds needed to financially support their criminal activities. As a result, the free flow of goods is hindered thus developments to address problems to stop or mitigate piracy lessened. This got 11 responses.

In rank 3 was the view: Pirate attacks can have widespread ramification including preventing humanitarian assistance and increasing the cost of future shipments to the affected areas. The criminal acts may result in the loss of life, physical harm or hostage taking to seafarers, significant disruptions to commerce and navigation, financial losses to ship owners, increased insurance premiums and security cost. Other responses were found on Table 5.

Finally when the respondents were asked about their views on how to combat piracy to attain international peace, the top three views were: As a marine official, full knowledge and idea and techniques for avoiding, preventing, and surviving pirate attacks is needed. A satellite system called shiplock allows shipping companies to monitor location of ships particularly useful if pirates attack, hijack or steal a ship and company also install non-lethal electrical fences round a ship's perimeter and IMO regulations require ships to be able to send distress signals and warnings covertly in case of pirate attack was in rank 1 with 13 responses; As a marine officer, the International Trade and Industry will take actions and create programs that will help whenever necessary. There are existing anti-piracy seminars and procedures on what to do if pirates attacked on board ship but on the other hand, pirates succeed in their operation. Today, there are vessels equipped with sophisticated anti-piracy equipment but unfortunately, there are ships which have none. As a suggestion, I think the International Shipping Management will work hand in hand to combat piracy and if possible deploy a stationary military ship to safeguard in that particular area in rank 2; and To combat piracy, the international community should have concerted effort to help Somalia establish its government to effectively check their organization by strict implementation of their anti piracy law was in rank 3 with 8 responses. The rest of their views are reflected in Table 6.

Table 5 Reasons for considering "piracy at sea" as a threat to international peace.

\begin{tabular}{lc}
\hline Reasons for considering piracy at sea as a threat to international peace & $f$ \\
\hline $\begin{array}{l}\text { Definitely piracy at sea is considered a threat to international peace for some reasons that shipping industry involved } \\
\text { international trade. Shipping companies are owned and operated by international owners and therefore if one of their }\end{array}$ & 14 \\
vessels was attacked by pirates the particular country wherein the vessel being registered will react and even \\
retaliate. In this case, there will be a fight between countries involved and therefore there will be a conflict with \\
regards to relationship globally. \\
$\begin{array}{l}\text { International peace is greatly threatened by piracy. Some terrorist organizations are using piracy to advance their } \\
\text { terroristic agenda by employing piracy to raise funds needed to financially support their criminal activities. As a }\end{array}$ & 11 \\
result, the free flow of goods is hindered thus developments to address problems to stop or mitigate piracy lessened. \\
$\begin{array}{l}\text { Pirate attacks can have widespread ramification including preventing humanitarian assistance and increasing the } \\
\text { cost of future shipments to the affected areas. The criminal acts may result in the loss of life, physical harm or }\end{array}$ & 9 \\
$\begin{array}{l}\text { hostage taking to seafarers, significant disruptions to commerce and navigation, financial losses to ship owners, } \\
\text { increased insurance premiums and security cost. }\end{array}$ & 3 \\
$\begin{array}{l}\text { Piracy is an organized group that is supported by their government and considered a threat to peace on the shipping } \\
\text { line. }\end{array}$ & 4 \\
$\begin{array}{l}\text { It disrupts trade and prevents orderly commerce growth. } \\
\text { It destroys live and millions of dollars lost in shipping companies/industries }\end{array}$ & 5 \\
\hline
\end{tabular}


Table 6 Views to combat piracy to attain international peace.

\begin{tabular}{lc}
\hline Views to combat piracy in order to attain international peace & $f$ \\
\hline As a marine official, full knowledge and idea and techniques for avoiding, preventing, and surviving pirate attacks is \\
needed. A satellite system called shiplock allows shipping companies to monitor location of ships particularly useful \\
if pirates attack, hijack or steal a ship and company also install non-lethal electrical fences round a ship's perimeter \\
and IMO regulations require ships to be able to send distress signals and warnings covertly in case of pirate attack. \\
$\begin{array}{l}\text { As a marine officer, the International Trade and Industry will take actions and create programs that will help } \\
\text { whenever necessary. There are existing anti-piracy seminars and procedures on what to do if pirates attacked on }\end{array}$ \\
$\begin{array}{l}\text { board ship but on the other hand, pirates succeed in their operation. Today, there are vessels equipped with } \\
\text { sophisticated anti-piracy equipment but unfortunately, there are ships which have none. As a suggestion, I think the }\end{array}$ & 10 \\
International Shipping Management will work hand in hand to combat piracy and if possible deploy a stationary & 2 \\
military ship to safeguard in that particular area. & 8 \\
To combat piracy, the international community should have concerted effort to help Somalia establish its & 3 \\
government to effectively check their organization by strict implementation of their anti piracy law. & 7 \\
All crew prior to boarding should undergo ship security awareness seminar. & 4 \\
Train seafarers to use firearms in order to fight piracy. & 5 \\
In order to combat piracy, seafarers should train to use firearms on board. & 4 \\
The ship/vessel should be escorted when passing HRA or piracy area. & 6 \\
\hline
\end{tabular}

\subsection{Views to Combat Piracy to Attain International Peace}

Piracy at sea is one of the issues confronted by IMO (International Maritime Organization) because this organization has been implementing an anti-piracy project-a long-term project which began in 1998. Phase one consisted of a number of regional seminars and workshops attended by government representatives from countries in piracy-infested areas of the world; while phase two consisted of a number of evaluation and assessment missions to different regions. IMO's aim has been to foster the development of regional agreements on implementation of counter piracy measures. Regional cooperation among states has an important role to play in solving the problem of piracy and armed robbery against ships, as evidenced by the success of the regional anti-piracy operation in the Straits of Malacca and Singapore. The Regional Cooperation Agreement on Combating Piracy and Armed Robbery against ships in Asia (RECAAP), which was concluded in November 2004 by 16 countries in Asia, and includes the RECAAP ISC (Information Sharing Centre) for facilitating the sharing of piracy-related information, is a good example of successful regional cooperation, which IMO seeks to replicate elsewhere.

Today, the deteriorating security situations in the seas off war-torn Somalia and the Gulf of Aden (and in the increasingly volatile Gulf of Guinea) are at the heart of the problem. In January 2009, an important regional agreement was adopted in Djibouti by states in the region, at a high-level meeting convened by IMO. The Djibouti Code of Conduct concerning the Repression of Piracy and Armed Robbery against Ships in the Western Indian Ocean and the Gulf of Aden recognizes the extent of the problem of piracy and armed robbery against ships in the region and, in it, the signatories declare their intention to cooperate to the fullest possible extent, and in a manner consistent with international law, in the repression of piracy and armed robbery against ships.

The signatories commit themselves towards sharing and reporting relevant information through a system of national focal points and information centers; interdicting ships suspected of engaging in acts of piracy or armed robbery against ships; ensuring that persons committing or attempting to commit acts of piracy or armed robbery against ships are apprehended and prosecuted; and facilitating proper care, treatment, and repatriation for seafarers, fishermen, other shipboard personnel and passengers subject to acts of piracy or armed robbery against ships, particularly those who have been subjected to violence.

To assist in anti-piracy measures, IMO issues reports on piracy and armed robbery against ships are 
submitted by Member Governments and international organizations. The reports, which include names and descriptions of ships attacked, position and time of attack, consequences to the crew, ship or cargo and actions taken by the crew and coastal authorities, are now circulated monthly, with quarterly and annual summaries.

\section{Conclusions}

Based on the findings of the present data, the conclusions of the study were advanced:

(1) Seafarers on board the international ships are aware of piracy at sea. The seafaring profession entails many challenges - one of these is piracy at sea;

(2) Seafarers considered "piracy at sea" as a threat to international peace. In response to this threat, IMO conducted series of talks, convention, and symposium on how to handle this type of international threat to the shipping and manning industry;

(3) Most of the views shared by the participants agreed that piracy at sea is considered as threat to international peace because the shipping industry involved international trade. Shipping companies are owned and operated by international owners and different countries, in case there will be hostages because of piracy, consequently, many countries will be involved and therefore the end result will be a conflict with regards to international-relationship;

(4) Full knowledge and idea and techniques for avoiding, preventing, and surviving pirate attacks is needed. A satellite system called shiplock allows shipping companies to monitor location of ships particularly useful if pirates attack, hijack or steal a ship and company also install non-lethal electrical fences round a ship's perimeter and IMO regulations require ships to be able to send distress signals and warnings covertly in case of pirate attack.

Implication of the Study:

The study on piracy at sea is very essential in the seafaring profession, specifically among marine engineering graduates of maritime university
(JBLFMU-Molo) who will be on board the international ships. The conception of the study was brought about in response to the call of international associations like IMO on fighting piracy at sea. Through this study, the College of Maritime Education, JBLFMU-Molo conducted series of seminars and symposium on "International Piracy" among graduating marine engineering and cruise ship management students who are going to go on board the international ships. Moreover, short course entitled "Shipboard Security and Management" was already in instituted at the college; the course was offered in order to inform the graduating marine engineering about the piracy and how to handle in case they were attacked by the pirates plying the HRA.

Recommendations:

After determining the results and conclusions of the present study, the following recommendations were advanced:

(1) The results of the study should be considered as basis for planning symposium on piracy at sea in order to heighten awareness among the maritime cadets;

(2) Additional seminars and conferences shall be conducted by MARINA and other maritime schools to help maritime students and seafarers to understand the consequences of piracy;

(3) Psychological effects of piracy among seafarers and their families shall be given consideration by selected professional psychologists;

(4) Studies on psychological, emotional, and traumatic impacts shall be studied in order to help the victims of international piracy.

\section{References}

[1] Beal, C. 2007. Quelch's Gold: Piracy, Greed, and Betrayal in Colonial New England. Praeger.

[2] Burnett, J. 2002. Dangerous Waters: Modern Piracy and Terror on the High Seas. Plume.

[3] Cordingly, D. 1997. Under the Black Flag: The Romance and the Reality of Life among the Pirates. Harvest Books.

[4] Evans, A. 2009. What Is the Meaning of the Descriptive Method in Research? Retrieved from eHow.com http://www.ehow.com/about_6663890_meaning-descripti 
ve-method-research_.html\#ixzz1AzFjNOzu.

[5] Girard, G. 2006. Tales of the Atlantic Pirates. Middle Atlantic Press.

[6] Kimball, S. 2006. The Pyrates Way Magazine. The Pyrates Way, LLC. http://www.pyratesway.com.

[7] Langewiesche, W. 2004. The Outlaw Sea: A World of Freedom, Chaos, and Crime. North Point Press.
[8] Menefee, S. 1996. Trends in Maritime Violence. Jane’s Information Group.

[9] Rediker, M. 1987. Between the Devil and the Deep Blue Sea: Merchant Seamen, Pirates and the Anglo-American Maritime World, 1700-1750. Cambridge University Press.

[10] The Economist. 2011. At sea: Piracy off the coast of Somalia is getting worse. Time to act. 